\title{
A Monitor Lizard in the Philippines
}

\section{Walter Auffenberg}

Until 1976 Gray's monitor lizard was known to science only by two museum specimens, neither of which gave any data more precise than 'Luzon'. In 1975 the author discovered a third which identified an area on Luzon, and in 1976 he went to the Philippines and found this large monitor, which some scientists had thought might be extinct, widely distributed in forests in southern Luzon. But large areas of these forests have been and continue to be destroyed, and with them go the monitor's habitat. Also local people hunt it for meat. The author discusses the ecology and distribution of the monitor and urges that a new national park be created.

Gray's monitor lizard Varanus grayi is an arboreal, canopy-inhabiting species, remarkable in that it feeds extensively on certain fruits. But, unless habitat destruction and hunting pressures are reduced, the remaining isolated populations may be in serious need of protection in the next decade or two.

Originally described in 1845 , the type specimen of this monitor is a juvenile in the British Museum of Natural History, bearing only the data, 'Philippines'. In 1942 a second specimen, a skull only, was located in the Berlin Museum, and described by Mertens; the only data for this was 'Luzon'. Thus, after 100 years the species was known to science on the basis of only two individuals, and both habitat and range were essentially unknown. In $1976 \mathrm{I}$ discovered and published a note on the discovery of a third specimen, a stuffed adult, in the United States National Museum. Of the three it had the only useful locality data-Pasacao, Luzon. Both this specimen and the Berlin skull suggested that $V$. grayi attained adult lengths of over one metre, making it one of the larger lizard species in the world, although one of the poorest known. Some herpetologists considered it as probably extinct. Its characteristic blunted teeth and large, compressed claws suggested it was arboreal and probably preyed upon tree snails and/or birds' eggs. In 1976 and again in 1978, aided by grants from the New York Zoological Society and the World Wildlife Fund, I was able to explore parts of Luzon and adjacent islands to determine the status, ecology, and distribution of this rare monitor, and managed to increase our knowledge of it considerably.

Called butaan in the Bicol Filipino dialect, sometimes bataua in Quezon, and baneas by the Aeta Negritos, Varanus grayi proved to be widely distributed in the remaining forested regions particularly in the Bicol region of southern Luzon. But even in undisturbed areas populations are small and the monitor is rarely seen. A list of the localities where it is now known to occur, based on specimens caught, seen, or reliably reported by experienced local hunters, is on page 46.

On both ecological and distributional grounds I believe this lizard may also occur along the entire east slope of the Sierra Madre, in Quezon Province, to near the north-east tip of Luzon, despite the fact that I could not confirm several reported sightings. There is no evidence that it occurs west of these mountains, nor is it found on the Bontoc Peninsula, which is adjacent to the main range in southern Quezon Province, the barrier being apparently climatic. I found it on Catanduanes, but not on the adjacent islands of Masbate or Samar. 


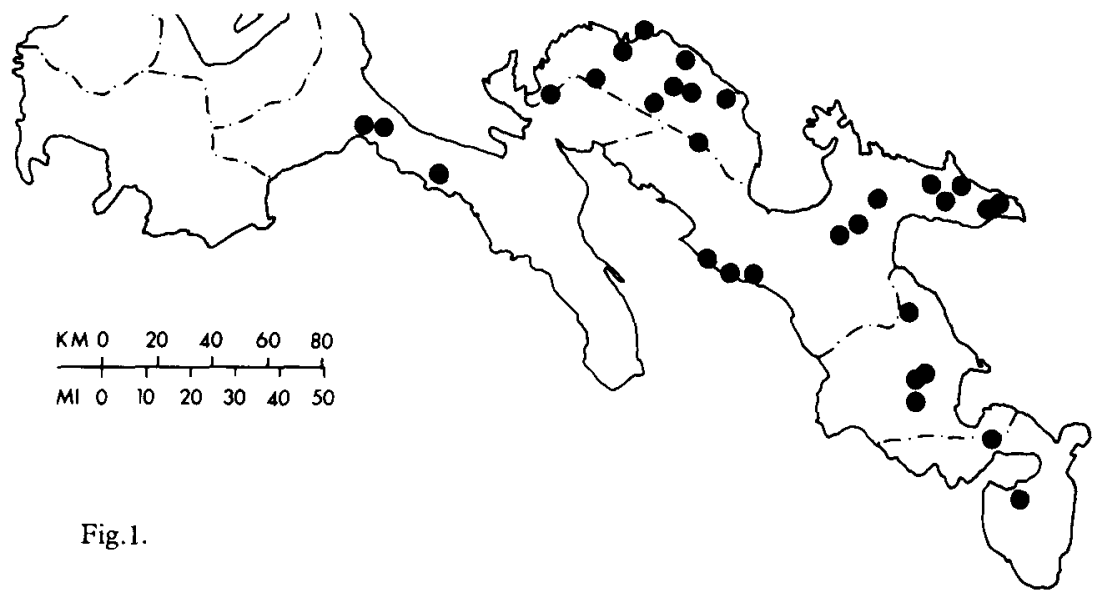

Fig 1. Southern Luzon; the dots show where monitors were caught, seen or reliably reported during the study. Luzon is the most northerly island in the Philippines.

Fig 2. Distribution dots show close relation to the dissected uplands indicated by cross-hatching.

Fig 3. Primary lowland dipterocarp forest of Caramoan Peninsula, Camarines Sur, Luzon, which is typical Varanus grayi habitat; shading shows where they are most commonly seen.

Fig 4. Major climatic zones of southern Luzon, showing correlation of Zones II and IV with the monitor's distribution.

Fig 5. Annual climatic pattern within II and IV and outside the monitor's range.

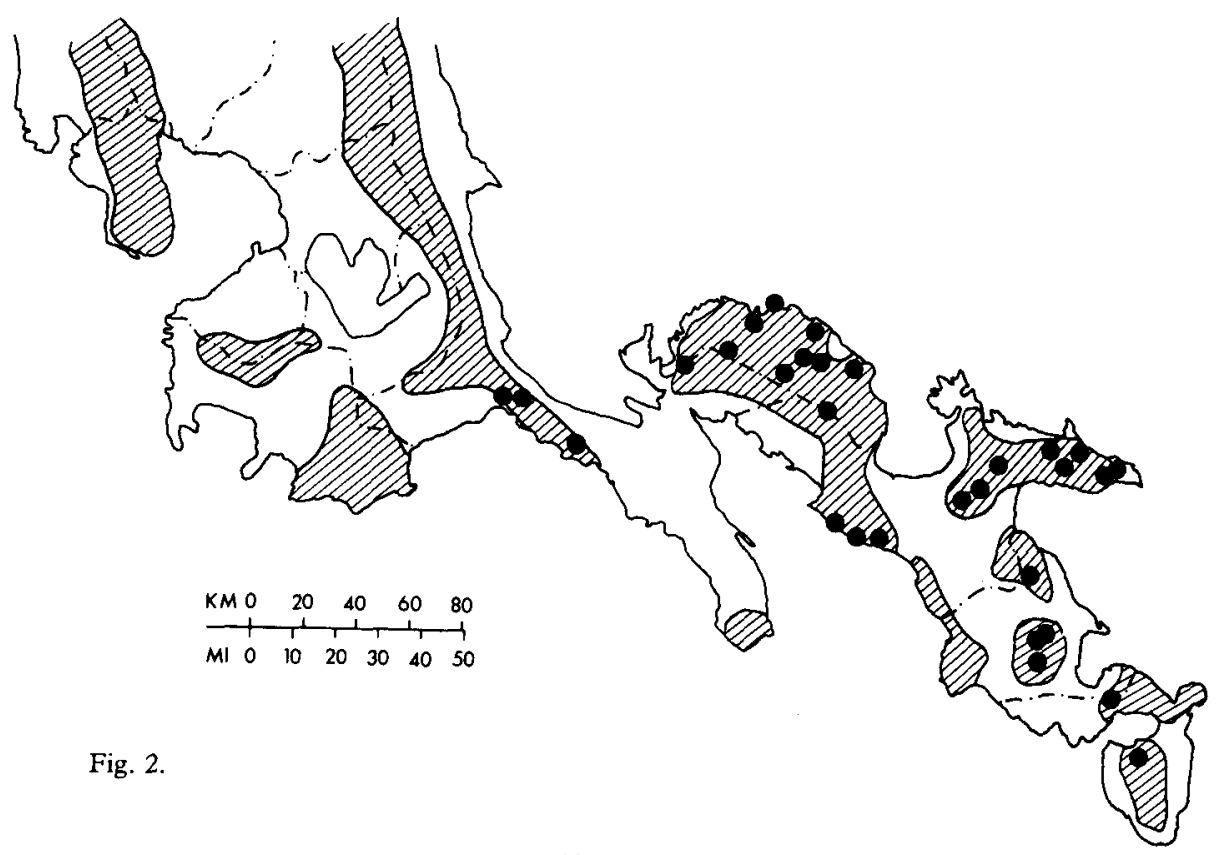




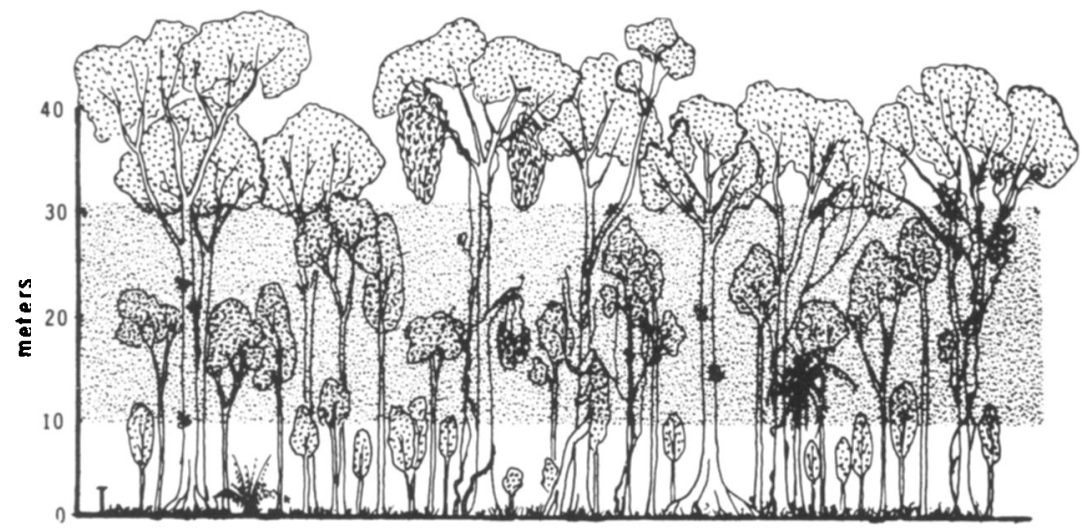

Fig. 3.

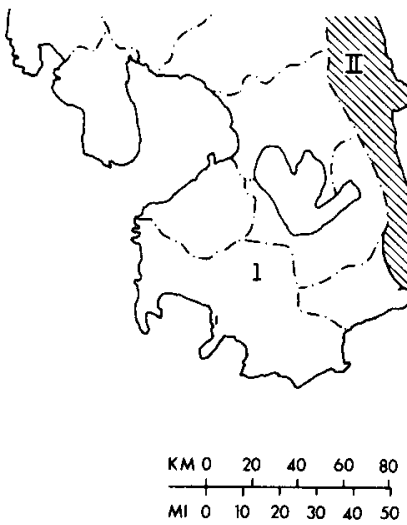

Fig. 4.

Fig. 5.
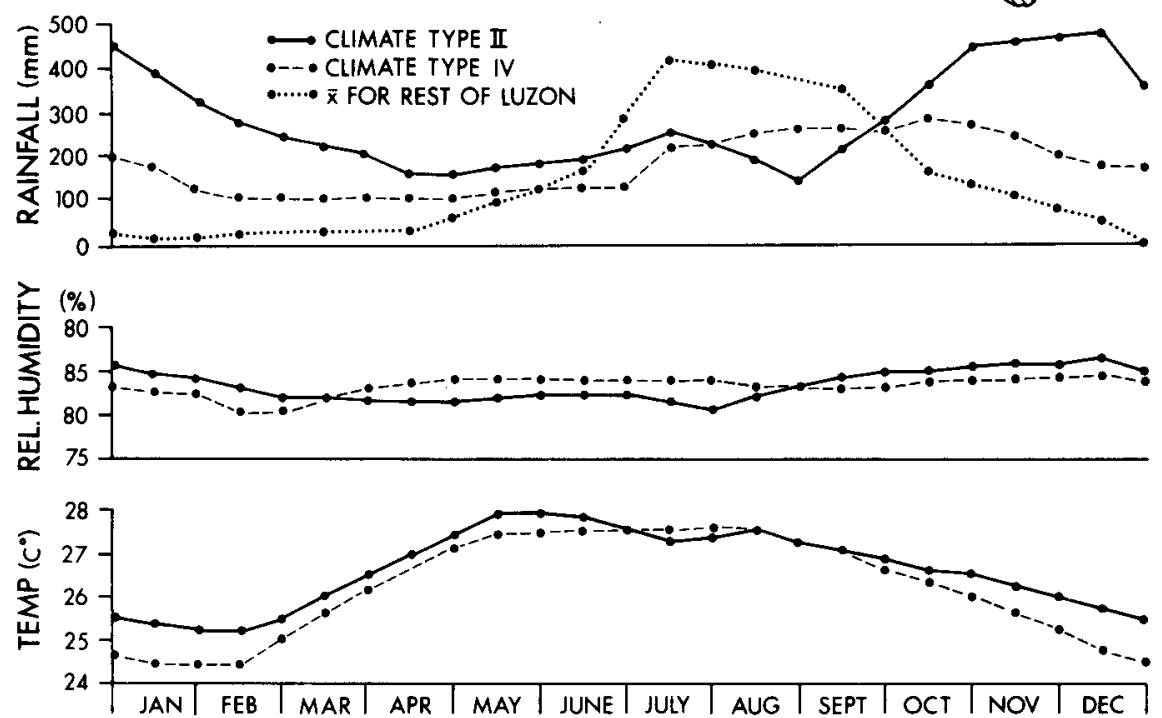
Within this large area, the butaan is restricted to the remaining forests dominated by broad-leaved tropical evergreens. Most of the original lowland forests within southern Luzon have been destroyed, thanks to urbanisation, lumbering and the spread of agriculture. It is not known whether the monitor ever occurred in them, for the remaining populations are more or less restricted to highly dissected, upland areas that have so far escaped clear cutting. But the fact that it is found near sea level, and also in habitats that were much more extensive in the past suggests that the populations were once much more widely distributed and that the remaining discontinuous ones are largely relictual. In the next decade continued land clearing and constant hunting pressure will undoubtedly restrict their distribution still further. A comparison of present known distribution with soil maps suggests that, originally, in the Bicol region alone, there were approximately 617,200 hectares of suitable habitat compared with 218,300 hectares today, a 65 per cent reduction. In addition the flesh of the butaan is relished, much above that of the locally more common V.salvator, and trained dogs and snares are used to catch them. Fortunately, no persistent use is made of the skin, though it occasionally reaches the leather market of Manila (where it is not particularly sought).

Varanus grayi is not normally found above $500 \mathrm{~m}$, apart from occasional wanderers. In Luzon this is the approximate upper limit of the tropical forests. In general, tree ferns mark its upper distributional limit and the beginning of the transition flora grading into a low montane type. Most of the substrate in its range is comprised of, or derived from, Early and Middle Tertiary volcanic rocks (andesites, conglomerates, breccias, and tuffs) and Late Tertiary and Pleistocene volcanics and coralline limestones, the latter usually highly karstified. Table 1 shows the major soils within the range, the approximate hectares in each type, and the commonest land use pattern. Figure 2 shows that throughout its present range the topography ranges from broken and hilly to mountainous, although before extensive logging and clearing for agriculture the butaan may have also been found in lower areas. Streams are numerous, and generally $20-30 \mathrm{~m}$ below the level of the surrounding area, often in narrow gullies or ravines.

Throughout its range lowland dipterocarp forest is the major vegetational association and its primary present habitat. Typically this forest is of a mixed lowland tropical type, its structure basically three stories of trees followed by shrubs and ground layers. Also characteristic are the great variety of woody species, many of them buttress-trunked, the profusion of lianas, the large number of palm species, and the high humidity.

The uppermost canopy reaches $30-40 \mathrm{~m}$ and is usually dominated by dipterocarps of the genera Parashorea, Pentacme, Shorea (several species), Dipterocarpus, and Hopea. Common tall non-dipterocarps include Canarium, Dracontomelon, and Palaquium. Near the forest edge many of these have been removed by logging. The middle layer averages $18-20 \mathrm{~m}$ high and includes many tree species, the commonest being members of the genera Hopea, Diplodiscus, Corida, Diospyros, Dillenia, Ficus (many species), Nephelium, Symplocos, and Livistona. In the lowest tree layer, 6-10 m high, species of the genera Carcinia, Laportea, Leea, Saurauia, and Grewia are common. The shrub layer, approximately $5 \mathrm{~m}$ high, consists mainly of Callicarpa, Clerodendron, and Tabernaemontana. These tree canopies tend to be irregular and open, so a dense undergrowth is characteristic, and the ground is usually 
Table 1 Soil type and Correlates within the range of Varanus grayi

Soil Type Total area (ha) Land Use

\begin{tabular}{|c|c|c|}
\hline Alaminos Clay & 58,668 & Generally upland forests \\
\hline Annam Clay Loam & 87,206 & $\begin{array}{l}\text { Mostly forested, some } \\
\text { coconuts }\end{array}$ \\
\hline Bulusan Loam & 6,770 & $\begin{array}{l}\text { Rolling to mountain } \\
\text { agriculture }\end{array}$ \\
\hline Casiguran Clay Loam & 38,120 & Usually hill agriculture \\
\hline Guinobatan Sandy Loam & 9,270 & Agriculture \\
\hline Lusiiana Clay & 140,379 & $\begin{array}{l}\text { Rolling to mountain } \\
\text { agriculture }\end{array}$ \\
\hline Macolod Sandy Loam & 26,793 & Hilly forest and agriculture \\
\hline Mayon Sandy Loam & 14,023 & Agriculture \\
\hline Sevilla Clay & 98,708 & Usually hill forest \\
\hline Tigaon Clay & 59,006 & $\begin{array}{l}\text { Rolling to mountain } \\
\text { agriculture, some forest }\end{array}$ \\
\hline Mt. Soils, Undiffer. & 108,931 & Mountain Forest \\
\hline
\end{tabular}

Total original habitat Bicol region only 617,218 ha

covered with ferns, seedlings, herbs, and mosses. Vines, climbing figs, and rattans hang from the trees, and the epiphytic flora includes mostly orchids and ferns.

The climate of the Philippines is often divided, according to rainfall distribution and amount, into four major zones. The monitor occurs only in Zones II and IV. Zone II, with no dry season, has a pronounced rainy season from July to February, with frequent cyclonic storms; it is restricted to a narrow strip along the east coast of Luzon, extending inland to the crest of the Sierra Madre Mountains (most of Quezon Province) in the northern and central parts of the island and the eastern half of the Bicol region of the southern part. Zone IV has no pronounced rainy season, and is restricted to the western part of southern Luzon. The rest of Luzon falls into Zone I, with a lower total annual rainfall and alternating distinct dry and wet seasons.

Within the range of $V$. grayi average rainfall is about $3000 \mathrm{~mm}$ (O.R. 2540$4064 \mathrm{~mm}$ ). In general, the region is overcast most of the year ( $\mathrm{x}$ number of cloudy days 187). Relative humidity is high and fairly uniform due to the nearby seas and the rich vegetation ( $x$ RH 78 per cent in April, 85 per cent in December, annual x 81.5 per cent). In a similar dipterocarp forest in central Luzon evaporation rate in the upper tree canopy can be over six times as great as in the ground layer. ${ }^{3}$

Temperatures in the forested lowland areas inhabited by the monitor are uniform; seasonal averages rarely vary more than $3-4^{\circ} \mathrm{C}$ and the daily range is often less than $3^{\circ} \mathrm{C}$. In similar forested situations in central Luzon, Brown and Matthews (1914) found that mean annual temperature is $23.1^{\circ} \mathrm{C}$; maximum $29.7^{\circ} \mathrm{C}$, and minimum $19.4^{\circ} \mathrm{C}$. Data on thermal stratification within the monitor's habitat were obtained by periodically taking temperatures at three different levels within the dipterocarp forest on the Caramoan Peninsula; in the lower part of the crown on a Parashorea plicata (a dominant, tall tree of the 
Table 2 Temperatures $\left(c^{\circ}\right)$ in dipterocarp forest habitat of V.grayi, Caramoan Peninsula, Camarines Sur, Luzon, Oct. 10-18

\begin{tabular}{lll}
\hline & X Maximum & X Minimum \\
\hline Undergrowth & 25.4 & 19.8 \\
Second Story & 25.6 & 20.7 \\
Upper Canopy & 33.1 & 20.3 \\
\hline
\end{tabular}

upper story), in the crown on a Dillenia philippinensis (a typical middle-story tree), and in the undergrowth at the surface level. Table 2 shows that during at least October 10-18 there is a little difference between temperatures of the lower and middle levels. Minima were almost equal in all three levels tested, but the maxima were clearly higher in the upper canopy. Thus an important thermoregulatory behaviour in this species probably includes considerable daily vertical movements.

While data regarding the range and ecology of Varanus grayi are now available, the rarity of the species and the difficulty of seeing it in the dense vegetation mean that it is little known among zoologists. But it is well known to the local rural folk, and their observations confirm my own that it is largely arboreal, spending much of each day and apparently most of the night in the trees. When seen, the monitors are usually between 10 and 30 metres up, often basking in the highest branches of the upper canopy. They are seldom seen on the forest floor, although in karst regions they are occasionally seen on cliff faces and limestone pinnacles. Aerial thickets of climbing bamboo Schizostachynum diffusum and rattan Calamus blanco are common hiding places, as well as hollow logs and trunks, and caves in limestone areas, rock slides, and burrows (of other animals or excavated by themselves) occasionally serve as retreats.

According to the Aeta Negritos, who eat this monitor and know it well, females lay 10-20 eggs, from March into June, usually in hollow standing trees, and only one clutch per year. The young are similar to the adults in colour and pattern and are also arboreal.

I was repeatedly told by native hunters that the monitor regularly feeds on fruits of several trees, and I was able to confirm this. The faeces of the adult specimen collected near Labo in Carmines Norte contained dozens of seeds of several fig and palm species, including buri Corphya elata and anahaw Livistonia rotundifolia palms and the climbing fig Ficus altissima. Local hunters also claimed that the adults commonly fed upon the fruits of the fish tail palm Caryota sp., the balading palm (sp.?), several other figs Ficus merritti, $F$.benjamina and F.balete, and pandanus Pandanus tectorius. They are said to shun banana, jack fruit, and papaya, and this was confirmed by the habits of a captive monitor kept in Gainesville, Florida.

No other monitor species is known to feed regularly on plant material, though Perry stated that $V$.salvator sometimes 'enters the fields and eats melons, cucumbers and rice' (not substantiated by any field or captive cases). ${ }^{9}$ Mertens reported that $V$.praesinus will sometimes eat bananas in captivity (substantiated by unpublished observations of others for this same species). ${ }^{8}$ It is very likely that in V.grayi vegetable food preferences are seasonally correlated, but no information is available. 
Adults are also said to feed on small rodents, birds and their eggs, and treesnails. In the Bicol region I found crushed shells of Rhysota otaheitana and $R$. cf. uranus in faecal pellets of $V$. grayi. Like other large varanids, these monitors frequently expel gastric pellets comprised of masses of feathers and/or hair after particularly large meals. They crush both birds' eggs and larger snails with their characteristic peg-like teeth, with the eggs tilting the head up so that the contents run down the throat. Negrito and Filipino hunters repeatedly said that this monitor (unlike salvator) does not feed on carrion; however the live captive in Florida eats both live and dead mice and birds.

This monitor is one of the larger varanid species in the world. The reference specimen obtained from the Caramoan Penisula has a total length of $1.50 \mathrm{~m}$ (estimated, because of broken tail), and the live captive is $1.41 \mathrm{~m}$ long $(0.55 \mathrm{~cm}$ snout-vent and $0.86 \mathrm{~cm}$ tail lengths: $4.25 \mathrm{~kg}$ ), and hunters who saw them said they were not unusually large, only slightly over average length. Individuals as long as $1.8 \mathrm{~m}$ can be expected in heavily forested, undisturbed, and littlehunted mountainous areas of the Bicol District and the more remote sections of Quezon Province, but occasional reports of three-metre specimens weighing up to $40 \mathrm{~kg}$ are considered exaggerations.

\section{Recommendations}

This investigation produced considerable information on the butaan's distribution and ecology. It also showed that lumbering and hunting are the major threats, disturbing the remaining populations to a degree that could become serious within a decade or two, although the recent government decree abolishing clear-cutting of forests and another decree stopping all hunting with guns will surely help to protect the butaan.

The largest surviving populations are believed to be in the heavily forested slopes of the mountain masses of northern Albay and southern Camarines Sur Provinces, the mountainous Caramoan Peninsula (where, however, a new national highway bisecting the area will soon open the forests to heavy exploitation), the large mountain mass of northern Camarines Sur and southern Camarines Norte (which includes the Bicol National Forest), and at least the south-east extensions of the Sierra Madre Mountains in Quezon Province. The largest single undeveloped forest block in its range is in the Bicol National Park area. This park should be enlarged to take in more of the forested mountain areas. * Unfortunately, the newly created Caramonan National Park in the highly karstified area (about $100 \mathrm{sq} \mathrm{km}$ ) east of Caramoan village is too small.

\section{Acknowledgments}

*This has now been done. Editor.

The expedition's success was largely due to the assistance and hospitality I received in Luzon. Appreciation is extended to Dr Godofredo L. Alcasid, Director of the Philippine National Museum, and to Mr Jesus B. Alvarez and his staff in the Bureau of Forest Development (Manila) for their help in expediting the work and solving logistic problems. Others without whose help in the initial and final stages success would have been impossible include Mrs Romi V. Gonzalez, Romeo Saldana, and Rubin L. Roxas, Manila. In the field work, I was extremely fortunate to have had the assistance of $\mathrm{Dr}$ Nilo Roa (Caramoan), and especially Drs Heracleo and Naida Guballa (Naga City). I also wish to thank the International Rotary Clubs of Luzon for their hospitality and many kindnesses during my visit, and to Coconut Comælex, Inc (Jose Panganiban City, Camarines Norte) for their attention to my needs in that area. My companions during most of the work were Messrs Edward Hellmich and William Holzmark (Sarasota, Florida), whose assistance in many ways is gratefully acknowledged. 


\section{References}

1. AUFFENBERG, WALTER 1976. First description of an adult Varanus grayi Copeia, 3.

2. BOULENGER, GEORGE A. 1885. Catalogue of the lizards in the British Museum (Natural History), Vol.2. London, Taylor and Francis.

3. BROWN, W. H., and D. H. MATTHEWS 1914. Philippine dipterocarp forests. Phil. F.Sci, 9.

4. GRAY, JOHN E. 1845. Catalogue of the specimens of lizards in the collection of the British Museum. London, Taylor and Franc1s.

5. HONEGGER, RENE E. and $H$. HEUSSER 1969. Beiträge zum Verhaltensinventar des Binden warans (Varanus salvator). Zool. Garten, 36.

6. LUCAS, LEWIS R., F. G. SALAZAR and L. ENGLE 1947. Soils of Camarines Norte. Bur. soils (Manila).

7. MARFORI, ROBERT T. 1948a. Soils of Sorsogon Province. 1948b, Soils of Albay Province. 1947, Soils of Camarines Sur Province. Bur. Soils (Manila).

8. MERTENS, ROBERT 1942. Die familie der Warane (Varanidae). Abhandle. senck. naturf. Ges. (Frankfurt a.M.), Nos. 462, 465, 466.

9. PERRY, NEIL E. 1932. Some notes on the water monitors in the Garo Hills, Assam. f. Bombay Nat. Hist. Soc., 35.

Dr Walter Auffenberg, Curator of Herpetology, Florida State Museum, Gainsville, Fl 32611 USA.

\section{Localities for Varanus grayi}

Camarines Sur Province: $\mathrm{Nr}$ Cayohoson, 3km E Buhi, nr Lake Buhi, E Mt Iriga, el. $300 \mathrm{~m}$; Pasacao, $20 \mathrm{~km}$ WSW Naga City, el. $250 \mathrm{~m}$ (United States National Museum No. 27776 and this study); $2 \mathrm{~km}$ W Sominabung $8 \mathrm{~km}$ NW Pasacao, el. $320 \mathrm{~m} ; 5 \mathrm{~km} \mathrm{~N}$ Dalupaon, $10 \mathrm{~km}$ NW Pasacao, el. $350 \mathrm{~m}$; nr Barrio Mayburi, $8 \mathrm{~km} \mathrm{~S} \mathrm{Minalabok,} 16 \mathrm{~km} \mathrm{~S}$ Naga City, el. ca 50m; nr Pacol, 8km ENE Naga City, el. ca 50m; 2km W Carolinas at Rayhan River, ca $10 \mathrm{~km}$ E Naga City, at base of Mt Isarog, el. ca 100m; Mayruhin, 23km E Naga City, Mt Isarog, el. ca $300 \mathrm{~m}$; nr Panicasan, $4 \mathrm{~km}$ E Carolinas, along Rayhan River, on slopes of Mt Isarog, el 400 m; 6km NW Lagonoy, ca $20 \mathrm{~km}$ E Mt Isarog, nr base of Caramoan Peninsula, el. ca $250 \mathrm{~m}$; nr Pagsagnaan, $4 \mathrm{~km}$ N Parubcan, S slope Calinigan Mts, Caramoan Penin., ca 40km ENE Mt Isarog, el. ca $350 \mathrm{~m}$; nr Caramoan, ca $16 \mathrm{~km}$ NWN of W tip of Caramoan Penin., el. ca $20 \mathrm{~m}$; nr Pandanan, $4 \mathrm{~km}$ NNW of W tip of Caramoan Peninsula, el. ca $20 \mathrm{~m}$; nr Ilawod, $2 \mathrm{~km}$ NE Caramoan, Caramoan Penin., el. $100 \mathrm{~m}$ (skin and skull reference specimen, Florida State Museum No. 37968); Barrio Minalaba, $5 \mathrm{~km}$ NW Caramoan, el. 60m; Patag, $7 \mathrm{~km}$ NW Caramoan, el. ca $50 \mathrm{~m}$; Mandiclom, $3 \mathrm{~km}$ S Gibgas, ca $24 \mathrm{~km}$ NW Caramoan, el. ca $100 \mathrm{~m}$; Ambuyog, $1.5 \mathrm{~km} \mathrm{~S}$ Gibgas, ca $24 \mathrm{~km}$ NW Caramoan, el. ca $50 \mathrm{~m}$; Toytoy, $10 \mathrm{~km}$ W Gibgas, el. $50 \mathrm{~m}$;

Camarines Norte Province: Bicol National Forest, where Highway No. 1 passes through it, nr boundary with Camarines Sur, el. $300 \mathrm{~m}$; Barrio Igang, $8 \mathrm{~km}$ NM Batbaloni, ca $24 \mathrm{~km} \mathrm{~W} \mathrm{Daet,} \mathrm{el.} 100 \mathrm{~m}$; Tinago, $5 \mathrm{~km} \mathrm{~S}$ iron mines, $5 \mathrm{~km} \mathrm{SW}$ Jose Panganiban, el. ca $100 \mathrm{~m}$; mts nr Talisay, ca $20 \mathrm{~km}$ Daet, el.?; $3.5 \mathrm{~m}$ W Labo, nr Bulhao, el. ca 80m; Barrio Malaya, 16km S Labo, el. 250m (Florida State Museum No. 7969, still alive in captivity as of this writing); Panganiban Penin., $5 \mathrm{~km}$ NE Panganiban, $\mathrm{nr}$ May Cruz, el. ca 50-100m; San Rafiel, $7 \mathrm{~km}$ W Panganiban, el. 50m; Barrio Macababale, el. ca $100 \mathrm{~m}$; Barrio Macagangke, $25 \mathrm{~km}$ W Labo, el $150 \mathrm{~m}$; nr Bulalon, el. $250 \mathrm{~m}$.

Quezon Privince: Nr Santa Elena, el. $250 \mathrm{~m} ; 2.5 \mathrm{~km}$ N Menahahan, 6km E Pagbilao, el. ca $200 \mathrm{~m}$; Quezon National Park, el. 200-400m.

Sorsogon Province: Mt Juban, nr Barrio Mt Irosin, $16 \mathrm{~km}$ S Sorsogon City, el. ca $350 \mathrm{~m}$ (skin reference specimen, Florida State Museum No. 37967); 8km NW Sorsogon City, Palge River, nr Barrio Capoy, el. ca $250 \mathrm{~m}$; nr Pilar, el. ca $100 \mathrm{~m}$.

Albay Province: $20 \mathrm{~km}$ NW Legaspi, along Benao River, nr Ligao, el. $200 \mathrm{~m} ; 0.3 \mathrm{~km}$ W Amtic, at Barrio Buang, between Mt Masaraga and Mayon volcano, $3 \mathrm{~km} \mathrm{E} \mathrm{Batang,} \mathrm{el.}$ $200 \mathrm{~km}$; SW slope Mayon volcano, $3 \mathrm{~km}$ E Masarauag. 